\title{
Improving self-efficacy with cognitive restructuring and self instruction: An experimental study in senior high school
}

\author{
Thisadewi Anggita, Sugiyo, Awalya
}

Universitas Negeri Semarang

thisadewianggita@gmail.com

Submitted : 09-05-2021, Revised : 18-05-2021, Accepted : 25-05-2021

\begin{abstract}
This study aims to analyze the effectiveness of cognitive behaviour therapy group counselling with cognitive restructuring techniques and effective self-instruction techniques to increase the self-efficacy of MA AlManar students. The population in this study were 136 students of MA AL Manar Semarang Regency, with a sample of 24 people consisting of 8 groups with cognitive restructuring techniques, 8 groups of self-instruction techniques, and 8 groups with cognitive restructuring techniques and self-instruction. Data collection techniques using a psychological scale. The data analysis technique used Paired Sample t-Test and One-Way Anova test. The results showed that the intervention carried out with cognitive restructuring technique group counselling and selfinstruction was effective to increase self-efficacy. These results imply the importance of guidance and counselling teachers to continue to develop the use of guidance and counselling services in dealing with student self-efficacy problems.
\end{abstract}

Keywords: cognitive restructuring techniques; group counseling; self-efficacy; self instruction technique.

\section{Introduction}

In the process of developing good and ideal individual abilities, self-efficacy plays an important role for students in school to actualize their abilities. If students already have selfefficacy in good condition, it will help them understand and believe in their ability to achieve goals in realizing the targets they have set and be responsible for the actions they have taken. Students with good personal abilities or confident abilities in themselves, can complete the task at hand and when they have a problem they will know how to deal with it. So that students become fully developed individuals because they believe in their abilities and they will be independent of all things related.

Research conducted by Sunawan., Yani, S.Y.A., Kencana, T.L., Anna, C.T., Mulawarman., \& Sofyan (2017) tates that self-efficacy encourages learning pleasure and maintains attention to student academic tasks. Furthermore, research conducted by Ana \& Wibowo (2017) shows the characteristics of the effectiveness of interventions on counselee self-efficacy, namely high motivation in solving problems, being open to the counsellor and not hesitating when having opinions or asking the counsellor.

Group counselling services as a way to increase student self-efficacy are deemed effective. Through group counselling, students get more opportunities to know their existence through experiences of group dynamics. Fitri \& Marjohan (2016) suggest that the overall benefits of group counselling services in solving student personal problems are very useful because after group counselling services are held students are able to communicate smoothly with others, be able to control themselves, be able to make good friendships. Habiba et al. (2017) in their research found that effective group counselling gave positive changes to students, namely that children began to recognize their potential, children had the courage to greet their teachers and friends and seniors, children had dared to appear in front of the class, and children had the courage to express their opinions in public forums., both inside and outside the school.

Research conducted by Setiawan (2015), Wijayanti (2016) dan Hasrul (2016) resulted in group counselling service models that can be combined with certain techniques to be more focused in their implementation and results, and the results in this study with effective counselling groups can increase efficacy. students' academic self on all indicators including cognitive and affective. Counselling that is able to understand the nature of emotional events, 
behavioural disorders, and focus on the cognitive content of individual reactions is counselling with a cognitive-behavioural approach. According to Sharf (2015) cognitive counselling is insight-oriented counselling that states recognition and changes negative thoughts and maladaptive beliefs. Cognitive counselling aims to change the way clients think by using their automatic thoughts to solve core schemes and begin to introduce the idea of schema restructuring. This is done by encouraging clients to gather and consider evidence to support their beliefs. Individuals tend to maintain their beliefs about themselves, their world, and their future.

The cognitive behaviour therapy (CBT) approach will help individuals to rebuild thought patterns (attitudes, assumptions and beliefs), test thought patterns, decide what is useful and what is not useful for individuals. The effectiveness of the cognitive behaviour therapy (CBT) approach has also been carried out by Asogwa et al. (2016) found that CBT was effective in increasing the academic self-efficacy of students in agricultural education programs and CBT was effective in improving the self-efficacy of male and female students. Therefore, it is recommended that university psychologists and counsellors should regularly implement cognitive behavioral therapy in Indonesia to increase student self-efficacy in educational sites.

The cognitive restructuring technique is a technique that is also taken from the cognitive behaviour therapy (CBT) approach. Cognitive restructuring techniques focus on identifying and changing negative thoughts or self-statements and irrational beliefs of the counselee. Research by Fadil et al. (2019) proved that cognitive restructuring strategies can reduce students' social anxiety and also reduce internet addiction.

Cognitive restructuring is thought to help students learn to maintain focus on assignments, prevent and reduce anxiety symptoms in students. Because cognitive restructuring techniques help students identify, challenge and change anxiety into irrational and self-destructive thought patterns and beliefs. The low sense of self-efficacy in school students is a problem that is often ignored by teachers, but if this situation continues to be ignored, this will have a negative impact on students, namely less than optimal learning outcomes. Self-efficacy affects students in choosing their activities. Giving cognitive restructuring strategies is considered suitable for correcting students' irrational beliefs as a basis for increasing self-efficacy.

Another technique used in increasing self-efficacy is self-instruction which is a technique of the cognitive behaviour therapy (CBT) approach which is an exercise to improve self-control by using self-verbalization as stimulation and strengthening during treatment, self-instruction techniques use positive verbal expressions to reduce negative thoughts and attempt to increase control over himself through his thoughts.

According to Martin \& Pear (2015) through self-instruction techniques, a person's negative view of himself can be directed to be more positive. The most important stage in the selfinstruction technique is that the individual slowly begins to speak softly in his heart (talking aloud to internal self-talk). Research findings by Dewi et al., (2016) suggest that the subject has increased social self-efficacy after being given treatment. Self-instruction techniques in cognitive-behavioural counselling are effective for increasing students' social self-efficacy. This technique is considered relevant to be used to increase low self-efficacy because it allows the counsellor to reshape cognitive patterns. However, this study found that the level of selfefficacy for each person varies according to individual characteristics. The purpose of this study was to analyze the effectiveness of cognitive behaviour therapy group counselling with cognitive restructuring techniques and effective self-instruction techniques to increase the selfefficacy of MA Al Manar students. 


\section{Methods}

The research used to answer this problem is quantitative approach research with experimental research methods. This is in accordance with the objectives of this study, namely to examine the causal relationship of two independent variables (cognitive restructuring techniques and self-instruction techniques) on the dependent variable (increasing student selfefficacy).

The population in this study were 136 students of MA AL Manar Semarang Regency, with a sample of 24 people consisting of 8 groups with cognitive restructuring techniques, 8 groups of self-instruction techniques, and 8 groups with cognitive restructuring and self-cognitive techniques. instruction. The sampling technique used in this study was the purposive sampling technique.

This study will use data collection techniques using a self-efficacy scale. Meanwhile, to collect supporting data, data collection techniques will be carried out in the form of questionnaires, interviews, observation and documentation. The data analysis technique in this study used the Paired Sample t-Test and One-Way Anova tests.

\section{Results and Discussion}

The results of the group counselling effectiveness test using cognitive restructuring techniques can be seen in the following table:

Table 1. Testing the Effectiveness of Group Counseling with Cognitive Restructuring Techniques to Improve Student Self Efficacy

\begin{tabular}{ccccccccc}
\hline & Mean & $\begin{array}{c}\text { Std. } \\
\text { Deviation }\end{array}$ & $\begin{array}{c}\text { Std. } \\
\text { Error } \\
\text { Mean }\end{array}$ & $\begin{array}{c}95 \% \text { Confidence } \\
\text { Interval of the } \\
\text { Difference }\end{array}$ & t & df & $\begin{array}{c}\text { Sig (2- } \\
\text { tailed) }\end{array}$ \\
\hline & & & \multicolumn{2}{c}{$\begin{array}{c}\text { Lower } \\
\text { Uper }\end{array}$} & \\
\hline $\begin{array}{c}\text { Group A } \\
\text { (Pre_Test) } \\
\text { (Post_Test) }\end{array}$ & 66.375 & 3.777 & 1.335 & 63.217 & 69.533 & 49.702 & 7 & .000 \\
\hline
\end{tabular}

In table 1 it is known that the difference in the average difference in the level of student self-efficacy before and after group counselling with cognitive restructuring techniques is 66.375. The value of $t$ count is 49,702 with a probability of 0,000 . When compared with the $\alpha$ value used (0.05), the calculated probability value is smaller than the $\alpha$ value, so that the hypothesis in this study is accepted, namely group counselling with cognitive restructuring techniques is effective for increasing student self-efficacy. This shows that there is a significant difference in student self-efficacy before and after group counselling with cognitive restructuring techniques.

Meitikasari (2015) research found that the things that make up self-efficacy in individuals through group counselling are built. Group counselling organizes social relationships between individuals in solving interpersonal problems, clients have the opportunity to practice new behaviour and clients learn interpersonal communication skills. The results of the group counselling effectiveness test with the self-instruction technique can be seen in the following table: 
Table 2. Testing the Effectiveness of Group Counseling with Self Instruction Techniques to Improve Student Self Efficacy

\begin{tabular}{|c|c|c|c|c|c|c|c|c|}
\hline \multicolumn{9}{|c|}{ Paired Differences } \\
\hline & \multirow[t]{2}{*}{ Mean } & \multirow[t]{2}{*}{$\begin{array}{c}\text { Std. } \\
\text { Deviation }\end{array}$} & \multirow[t]{2}{*}{$\begin{array}{l}\text { Std. } \\
\text { Error } \\
\text { Mean } \\
\end{array}$} & \multicolumn{2}{|c|}{$\begin{array}{l}95 \% \text { Confidence } \\
\text { Interval of the } \\
\text { Difference }\end{array}$} & \multirow[t]{2}{*}{$\mathbf{t}$} & \multirow[t]{2}{*}{ df } & \multirow[t]{2}{*}{$\begin{array}{l}\text { Sig (2- } \\
\text { tailed) }\end{array}$} \\
\hline & & & & Lower & Uper & & & \\
\hline $\begin{array}{c}\text { Group B } \\
\text { (Pre_Test) } \\
\text { (Post_Test) }\end{array}$ & 76.750 & 7.046 & 2.491 & 70.860 & 82.640 & 30.810 & 7 & .000 \\
\hline
\end{tabular}

In table 2 it is known that the difference between the average level of student self-efficacy before and after group counselling with self-instruction techniques is 76,750 . The value of $t$ count is 30,810 with a probability of 0,000 . When compared with the $\alpha$ value used (0.05), the calculated probability value is smaller than the $\alpha$ value, so the hypothesis in this study is accepted, namely group counselling with effective self-instruction techniques to reduce student self-efficacy. This shows that there is a significant difference in the level of student selfefficacy before and after group counselling with self-instruction techniques.

Dewi et al. (2016) social persuasion, which has an induction model, including suggestions, advice, self-instruction and interpretive therapy. In addition, several studies that have been conducted mention that some verbal influences are shown to influence the level of self-efficacy on the success of carrying out an activity. The results of group counselling effectiveness tests with combined cognitive restructuring techniques and self-instruction techniques can be seen in the following table:

Table 3.Testing the Effectiveness of Group Counseling with Cognitive Restructuring Techniques Integrated with Self-Instruction Techniques to Improve Student Self Efficacy

Paired Differences

\begin{tabular}{ccccccccc}
\hline & Mean & $\begin{array}{c}\text { Std. } \\
\text { Deviation }\end{array}$ & $\begin{array}{c}\text { Std. } \\
\text { Error } \\
\text { Mean }\end{array}$ & $\begin{array}{c}\text { 95\% Confidence } \\
\text { Interval of the } \\
\text { Difference }\end{array}$ & T & df & $\begin{array}{c}\text { Sig (2- } \\
\text { tailed) }\end{array}$ \\
\hline & & & & Lower & Uper & & \\
\hline $\begin{array}{c}\text { Group C } \\
\text { (Pre_Test) } \\
\text { (Post_Ttest) }\end{array}$ & 81.375 & 9.164 & 3.240 & 73.714 & 89.036 & 25.116 & 7 & .000 \\
\hline
\end{tabular}

In table 3, it is known that the difference between the average level of student selfefficacy before and after group counselling with self-instruction techniques is 81.375. The value of $t$ count is 25,116 with a probability of 0,000 . When compared with the $\alpha$ value used (0.05), the calculated probability value is smaller than the $\alpha$ value, so the hypothesis in this study is accepted, namely group counselling with combined cognitive restructuring techniques and effective self-instruction techniques to reduce student self-efficacy. This shows that there is a significant difference in the level of student self-efficacy before and after group counselling with combined cognitive restructuring techniques and self-instruction techniques.

The results of the test of the difference in effectiveness between the group counselling of cognitive restructuring techniques, self-instruction techniques and a combination of cognitive restructuring and self-instruction techniques to improve student self-efficacy with the following Anova test techniques: 
Table 4. ANOVA Test Results

\begin{tabular}{llllrl}
\hline & Sum of Squares & df & Mean Square & F & Sig. \\
\hline Between Groups & 726.333 & 2 & 45.396 & 13.070 & .000 \\
\hline Within Groups & 103.500 & 2 & 14.786 & & \\
\hline Total & 829.833 & 23 & & & \\
\hline
\end{tabular}

From table 4 above, it can be seen that the probability value (P-Value) is 0,000 . When compared with the $\alpha$ value used (0.05), the calculated probability value is smaller than the $\alpha$ value. Thus the hypothesis in this study is accepted "There is a difference in effectiveness between the cognitive restructuring technique group counselling, the group counselling of the self-instruction technique and the combined group counselling of cognitive restructuring and self-instruction techniques to improve students' self-efficacy." This means that there are significant differences between the three groups before and after being given group counselling with cognitive restructuring techniques, self-instruction and a combination of cognitive restructuring and self-instruction techniques.

\section{Conclusions and Suggestions}

Based on the results of research conducted on the effectiveness of cognitive restructuring and self-instruction group counselling services in increasing the self-efficacy of MA Al-Manar students, it can be concluded that the intervention carried out with group counselling combined cognitive restructuring techniques and self-instruction is effective to increase self-efficacy, and there are different levels of effectiveness in cognitive restructuring techniques and selfinstruction techniques in increasing student self-efficacy. The results of this study are expected to be a model of a counselling approach that can be applied by guidance and counselling teachers in overcoming student self-efficacy problems.

Suggestions based on the results of the study are that counselling teachers can apply group counselling with cognitive restructuring techniques and self-instruction techniques to increase student self-efficacy. For further researchers, it is hoped that they can research and find the most appropriate strategies applied by guidance and counselling teachers to increase student self-efficacy.

\section{References}

Ana, A., \& Wibowo, M. E. (2017). Bimbingan Kelompok dengan Teknik Role Playing untuk Meningkatkan Self-Efficacy dan Harapan Hasil (Outcome Expectations) Karir Siswa. Jurnal Bimbingan Konseling, 6(1), 49-53. https://journal.unnes.ac.id/sju/index.php /jubk/article/download/17434/8791/.

Asogwa, V. C., Ojogbane, V. J., \& Idoko, E. J. (2016). Effect of Cognitive Behaviour Therapy on Self-Efficacy of Students of Agricultural Education Programme in Nigerian Universities. International Journal of Innovative Social and Science Education Research, 4(June), 47-57. https://seahipaj.org/journals-ci/june-2015/june2016/IJISSER/full/IJISSER-J-8-2016.pdf.

Creswell, J. W. (2015). Penelitian Kualitatif \& Desain Riset. Yogyakarta : Pustaka Pelajar.

Dewi, F. A., Atmoko, A., \& Triyono. (2016). Kefektifan Teknik Self Instruction dalam Konseling Kognitif-Perilaku untuk Meningkatkan Efikasi Diri Sosial Siswa SMKN 2 Malang. Jurnal Kajian Bimbingan Dan Konseling 1, 4, 172-178. https://doi.org/http://dx.doi.org/10.17977/um001v1i42016p172. 
Fadil, M., Sunawan, \& Awalya. (2019). The Effectiveness of Group Counselling with Cognitive Restructuring and Self-Management Techniques to Reduce Internet Addiction. Jurnal Bimbingan Konseling. JUBK $8, \quad 8 \quad$ (1), 134-139. https://doi.org/https://doi.org/10.15294/jubk.v8i2.28172.

Fitri, E. N., \& Marjohan. (2016). Manfaat Layanan Konseling Kelompok Dalam Menyelesaikan Masalah Pribadi Siswa. Jurnal Pendidikan Indonesia. Jurnal Pendidikan Indonesia, 2 (2), 19-24. http://jurnal.iicet.org/index.php/j-edu/article/download/61/64.

Habiba, A., Wibowo, M. E., \& Jafar, M. (2017). Model Konseling Kelompok Teknik Self Instruction untuk Meningkatkan Self Confidence Siswa SMP. JUBK 6, 6 (1), 1-6. https://journal.unnes.ac.id/sju/index.php/jubk/artice/download/17419/8784/.

Hasrul. (2016). Efektifitas Konseling Kelompok Dengan Teknik Metafora Berbentuk Healing Stories Untuk Meningkatkan EfikasiDiri Akademik Siswa SMA. Jurnal Realita, 1 (April). http://web.fuberlin.de/gesund/publicat/ehps_cd/health/indonese.htm.

Martin, G., \& Pear, J. J. (2015). Behavior modification: What it is and how to do it. New York: Psychology Press.

Setiawan, M. A. (2015). Model Konseling Kelompok Dengan Teknik Problem Solving Untuk Meningkatkan Self Efficacy Akademik Siswa. JUBK 4, 4 (1), 8-14. https://journal.unnes.ac.id/sju/index.php/jubk/article/view/6869.

Sharf, R. S. (2015). Theories of Psychotherapy and Counseling Concepts and Cases. 5Th Ed. Ed.Boston: Cengage Learning, Inc.

Sugiyono. (2015). Metode Penelitian Pendidikan (Pendekatan Kuantitatif, Kualitatif dan $R \& D)$. Bandung: Alfabeta.

Sunawan., Yani, S.Y.A., Kencana, T.L., Anna, C.T., Mulawarman.,\& Sofyan, A. (2017). Dampak Efikasi Diri terhadap Beban Kognitif dalam Pembelajaran Matematika dengan Emosi Akademik sebagai Mediator. Jurnal Psikologi, 44(1), 28-38. https://doi.org/10.22146/jpsi.22742.

Wijayanti, P. A. K. (2016). Konseling Kelompok Untuk Meningkatkan Efikasi Diri Dalam Pengambilan Keputusan Karir. Intuisi $8, \quad 8 \quad$ (3), 163-172. https://journal.unnes.ac.id/nju/index.php/INTUISI/article/download/8638/5695. 